Vol. 28, No. 1, June 2021

P-ISSN: 0854-8919, E-ISSN: 2503-1023

Nationally Accredited Journal, Decree MoHE No. 148/M/KPT/2020.

\title{
Implications of Legal Loophole concerning Liability over Delay in Restitution Payment by Criminal Offender
}

\author{
Nurini Aprilianda*, Ryan Ilham Fibriansyah \\ Faculty of Law, Universitas Brawijaya, Indonesia \\ *Corresponding author: aprilianda@yahoo.co.id
}

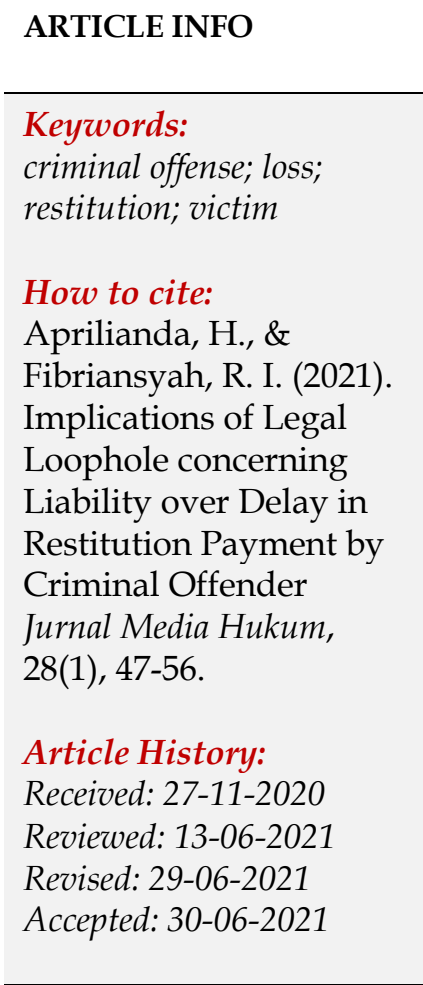

\begin{abstract}
Crime is harmful to society, especially to the victims. Legal protection should be taken into account to help the victims recover from the loss suffered. The protection can be made through the payment of restitution by either the offender or the third party. Such an issue has been addressed in the existing law, especially the Witness and Victim Protection Act 2014 (Amendment) and the Government Regulation No. 7 of 2018 concerning Compensation, Restitution, and Aid for Witness and Victim. Unfortunately, they do not impose any sanction over the delay in restitution payment by the third party or the offender. This paper aims at discussing the implication of this legal loophole. This normative legal research employs a statutory approach. It is found that the legal loophole has exposed the victims to secondary victimization due to uncertainty and injustice.
\end{abstract}

DOI: https://doi.org/10.18196/jmh.v28i1.10411

Copyright @ 2021 JURNAL MEDIA HUKUM. All rights reserved.

\section{Introduction}

Crime continuously develops along with the development of society. The crime itself keeps people vigil and causes disruption. Criminal offenses are against the law, whether they are committed intentionally or not, and punishable by law in reference to the provisions of the law where sanctions are based on. ${ }^{1}$

Victimization has no limit, and everyone can be prone to it under any condition, where victims are likely to suffer from all the loss due to the offenses committed. The loss the victims have to bear due to the offenses takes the financial loss, physical, mental, or social form. The victims are defined as those physically injured or suffered from mental illness, or those having to lose their assets or those who are dead due to the offenses committed. ${ }^{2}$

\footnotetext{
${ }^{1}$ Gunadi, I. \& Efendi, J. (2014). Cepat \& Mudah Memahami Hukum Pidana. Jakarta: Kencana, p. 36

2 Farhana. (2012). Aspek Hukum Perdagangan Orang di Indonesia. Jakarta: Sinar Grafika, p. 158
} 
In the situation where victims mostly suffer from the loss caused, legal protection is required. The Criminal Judicial System in Indonesia, however, pays more attention to the offenders rather than the victims and the victimizations are sometimes seen as an accident or bad luck. ${ }^{3}$ Victims' rights demand attention too and they are obviously governed by the existing legislation. Law No. 31 of 2014 concerning Amendment of Law No. 13 of 2006 concerning Protection of Witnesses and Victims, implies that there are measures taken to fulfil their rights and provide some help to give security to the victims, and all these measures are compulsory for the Organization of Protection of Witnesses and Victims (hereinafter LPSK) or other appropriate organizations to take. 4 This protection may be extended to other measures such as restitution, compensation, medical treatment, and legal aid. ${ }^{5}$

Restitution and compensation serve a similar objective that is to pay back the loss sustained by the victims. The difference is only on the party who should be responsible for it. Restitution is paid by the offender or related third party to the victim or his family, in which the restitution may constitute the return of the lost asset due to a criminal offense, the payment over the lost asset, or the payment over certain actions. ${ }^{6}$ On the other side, compensation is paid by the state as a manifestation of the community's responsibility. Restitution is stated in Law No. 31 of 2014 concerning Amendment to Law No. 13 of 2006 concerning Protection of Witnesses and Victims. The main purpose of restitution is to pay back the loss sustained by the victim due to the commission of a criminal offense.

Article 7B of Law No. 31 of 2014 concerning Amendment to Law No. 13 of 2006 concerning Protection of Witnesses and Victims states that "further provisions concerning guidelines of request and arrangement of compensation and restitution as intended in Article 7 and Article 7A are governed in government regulation." Therefore, all guidelines of request and all the process of arrangement of restitution are elaborated in the provisions of Article 19 to Article 36 of Government Regulation No. 7 of 2018 concerning Compensation, Restitution, and Aid for Witnesses and Victims.

The Government Regulation No. 7 of 2018 has a loophole over the arrangement or restitution given to the victim, and this loophole is obvious in the provision of Article 35 of Government Regulation No. 7 of 2018 concerning Arrangement of Compensation, Restitution, and Aid for Witnesses and Victims:

1. If the payment of restitution is made through an installment, each installment or payment delay must be reported by the victim, family, or another party assigned by the victim to LPSK and send its copy to a court head.

2. If this restitution is arranged based on a court decision, the LPSK must report the installment or the delay to the public prosecutor.

Article 35 Paragraph 1 of Government Regulation No. 7 of 2018 concerning Arrangement of Compensation, Restitution, and Aid for Witnesses and Victims implies that restitution can be made through an installment by the offender to the victim, and

\footnotetext{
3 Sunarso, S. (2012). Viktimologi dalam Sistem Peradilan Pidana. Jakarta: Sinar Grafika, p. 9

${ }_{4}^{4}$ Article 1 Paragraph 8 of Law No. 31 of 2014 concerning Amendment to Law No. 13 of 2006 concerning Protection of Witnesses and Victims

${ }^{5}$ Yulia, R. (2013). Viktimologi Perlindungan Hukum terhadap Korban Kejahatan. Yogyakarta: Graha Ilmu, p. 178

${ }^{6}$ Ransun, A. R.V. (2012). Mekanisme Pemberian Kompensasi dan Restitusi bagi Korban Tindak Pidana. Jurnal Lex Crimen, 1.
} 
as mentioned, each installment and delay are to be reported to LPSK and send its copy to a court head, but no consequences are stated in case of payment delay. The weaknesses of regulations raised an issue concerning what are the legal implications of the absence of legal liability over payment delay or refusal to pay restitution to victims suffering from criminal offenses in Indonesian legislation.

\section{Method}

This paper is constructed based on normative legal research. This normative legal research employs a statutory approach and relies on secondary data in the form of legal materials. The primary legal materials consist of Article 99 and 100 of Law No. 8 of 1981 concerning Criminal Procedure Law, Article 7A of Law No. 31 of 2014 concerning Amendment to Law No. 13 of 2006 concerning Protection of Witnesses and Victims, and Government Regulation No. 7 of 2018 concerning Compensation, Restitution, and Assistance to Witnesses and Victims. The legal materials are further systematized and interpreted based on systematical and teleological methods.

\section{Analysis and Results}

3.1. The implication of Legal Loophole concerning Liability of Delay or Absence of Restitution for Victims of Crimes in Indonesia.

\subsubsection{Definition and Objective or Restitution}

Restitution is aimed to pay back all the loss a victim suffers and restitution holds an essential position for the victim to help him/her recover the loss, as stipulated in the Declaration of Basic Principle of Justice for Victim of Crime and Abuse of Power. ${ }^{7}$ Restitution is also highlighted in Basic Guidelines on the Right to a Remedy and Reparation for Victims of Violations of International Human Rights and Humanitarian Law clearly stating that victims are entitled to five rights of reparation that comprise restitution, compensation, rehabilitation, satisfaction, and guarantees of nonrepetition. ${ }^{8}$

Restitution serves as a connecting bridge that leads to the embodiment of resocialization of social responsibility within an offender as an individual. ${ }^{9}$ Restitution is aimed to encourage a criminal to be responsible for the consequence of the crime committed, which involves the recovery of loss the victim suffers from. This description is in line with the definition or restitution governed in the provision of Article 1 No. 11 of Law No. 31 of 2014 concerning Amendment to Law No. 13 of 2006 concerning Protection of Witness and Victims stating, "restitution is a form of redress paid to the victim or his/her family to recover the loss caused by the offender or the third party." 10

\footnotetext{
7 Yulia, R., op. cit p. 58

8 Marlina \& Zuliah, A. (2015). Hak Restitusi terhadap Korban Tindak Pidana Orang. Bandung: Refika Aditama, p.41

${ }_{9} \mathrm{Ibid}, \mathrm{p} .40$

10 Article 1 Paragraph 11 of Law No. 31 of 2014 concerning Amendment to Law No. 13 of 2006 concerning Protection of Witnesses and Victims.
} 
Restitution is defined as a measure to recover the loss caused where a certain amount of money is paid to recover the situation (Restutio in integrum). ${ }^{11}$ From the intention of restitution to recoup all the loss the victim may suffer from, it can be said that restitution is also aimed to bring justice to the victim by bringing all his/her rights back.

Restitution is a concept of law having existed in history, which is quite apparent in the legal system ever existing in the society of ancient time even before law split into civil and criminal law. Restitution is a standard norm a criminal offender has to pay to a victim of the crime or the victim's family, and this restitution arises from the violation committed. In ancient times, restitution was not only intended for the recovery of the victims, but it was also to avert any potential of retaliation coming from the victims or the members of the public. ${ }^{12}$

Galaway asserts that the exercise of restitution principally has four benefits as follows:

1. Restitution serves as a requirement of probation that allows the court to alleviate a criminal sentence;

2. Restitution helps recover the dignity of criminal offenders by encouraging them to pay for what they have committed;

3. Restitution is imposed as a criminal sanction that is affordable in substitution for jail sentences;

4. Restitution is believed to be able to fulfill the psychological satisfaction of the victims ${ }^{13}$

\subsubsection{The connection between Restitution and Restorative Justice}

As mentioned, that restitution is understood as Restutio in integrum, it is also connected to restorative justice. United Nations Office on Drugs and Crime in Handbook on Restorative Justice Programs obviously states "Restorative justice refers to a process for resolving crime by focusing on redressing the harm done to the victims, holding offenders accountable for their actions and, often also, engaging the community in the resolution of that conflict." 14 Thus, restorative justice does not encourage any retaliation against criminal offenders, but it is rather emphasized on supports and help given to the victims. ${ }^{15}$ Restorative justice focuses on the remedy over loss caused due to the offense harming the victim, where liability is imposed on the offender for the remedy of the loss caused. Therefore, restorative justice is expected to serve as an alternative measure regarding criminal offenses by emphasizing the recovery of the victims and the harmony between the criminal offenders and the victims. ${ }^{16}$ Therefore, restorative

\footnotetext{
11 Marasabessy, F. (2015). Restitusi bagi Korban Tindak Pidana: Sebuah Tawaran Mekanisme Baru. Jurnal Hukum dan Pembangunan, 45(1), p. 55

12 Al-Eifan, M. \& Alayash, M. (2014). Victim Restitution in the Kuwait Legal System: A Criminal or Civil Remedy? Comparative Analysis. International Review of Penal Law, 85, p. 701

${ }^{13}$ Ali, M. \& Wiboro, A. (2018). Kompensasi dan Restitusi yang Berorientasi pada Korban Tindak Pidana. Yuridika,33(2), p. 268

14 United Nations Office on Drugs and Crime. (2006). Handbook on Restorative Justice Programs. New York: United Nations Publication, p. 6

${ }^{15}$ Mareta, J. (2018). Penerapan Restorative Justice melalui Pemenuhan Restitusi pada Korban Tindak Pidana Anak. Jurnal Legislasi Indonesia, 15(4), p. 313

16 Sosiawan, U.M. (2016). Prespektif Restorative Justice sebagai Wujud Perlindungan Anak yang Berhadapan dengan Hukum. Jurnal Penelitian Hukum De Jure, 16(4), 426.
} 
justice deals with the redress for loss triggered by an offense that harms the victim, and this harm has imposed liability to recover the situation. ${ }^{17}$

Regarding the connection between restitution and restorative justice as mentioned earlier, it is obvious that restitution provided for the victims principally holds the restorative justice values as outlined by Umbret in the following:

1. Restorative justice is more emphasized on the recovery of the victims and a community instead of the offenders;

2. Restorative justice involves the role of the victims in the process of criminal proceedings through their participation, suggestions, and services;

3. Restorative justice encourages a community to get involved in the recovery of the victims and offenders;

4. Restorative justice is to raise awareness to understand that the responsibilities of a community towards social conditions affect what is committed. ${ }^{18}$

As highlighted by Umbret, restitution serves as a mechanism to provide recovery in order to return the victims into condition prior to victimization. Thus, this redress as outlined in the provisions of restitution is aimed to make an offender directly repay what a crime has caused.

Once again, restorative is more emphasized on the victims and the members of society to give responsibilities to offenders for what they have committed by turning the situations back to normal. ${ }^{19}$ Seemingly there is a similarity between the two, as both are concerning the remedy of the loss aimed to raise the liability the offender has to take for the offense he/she commits against the victim. This is in line with the principle of restorative justice that puts the liability of the offender first.

Despite this identical feature of the two, the basic difference is obvious in terms of punishment, where restorative justice is more focused on the recovery of the victim. Thus, restorative justice tends to allow clemency given by the victim to the offender and resolution of crime through penal mediation. In terms of the arrangement or restitution, it is obvious that the process of redress should take into account the litigation process or proceedings recorded in a court decision. Restitution is often seen as retaliation against the offender imposed by a responsibility of paying the restitution while the offender still has to serve his/her sentence.

3.2. Inadequacy of the Government Regulation concerning Arrangement of Compensation, Restitution, and Aid to Witnesses and Victims and its Juridical Implication

3.2.1. Legal Loophole and Inadequacy in the Government Regulation concerning Arrangement of Compensation, Restitution, and Aid for Witnesses and Victims

A victim is defined as a person who suffers from loss caused by a criminal offense committed by an offender. In such a case, the victim deserves recovery that involves restitution or compensation according to the provision of Law concerning Protection of

${ }_{17}$ Gunawan, T.J. (2018). Konsep Pemidanaan Berbasis Nilai Kerugian Ekonomi. Jakarta: Kencana, p. 106

18 Flora, H. S. (2017). Pendekatan Restorative Justice dalam Penyelesaian Perkara Pidana dalam Sistem Peradilan Pidana di Indonesia. Law Pro Justitia, 2(2), p. 54.

19 Satria, H. (2018). Restorative Justice: Paradigma Baru Peradilan Pidana. Jurnal Media Hukum, 25(1), p. 117 
Witnesses and Victims, where restitution is paid by the offender while compensation is the responsibility of the state. Specifically, restitution arrangement is governed in the law concerning Witnesses and Victims, which is further elaborated in the provision of Government Regulation No. 7 of 2018 concerning Arrangement of Compensation, Restitution, and Aid for Witnesses and Victims.

Providing restitution is a pillar underpinning the presence of justice for the victims or to recover all the loss the victims have to take due to the criminal offenses caused. This condition is congruent with what Cortney Lollar expresses:
"Traditionally, in both the civil and criminal contexts, restitution was used to financially restore a person economically damaged by another's actions, thereby preventing the unintended beneficiary from being unjustly enriched at the aggrieved party's expense. 20

Thus, it is obvious that restitution is intended to recover all financial loss caused by crimes, and restitution should normally be enforced and implemented for the sake of justice for the victims of criminal offenses.

Furthermore, in reference to government regulation concerning Compensation, Restitution, and Aid for Witnesses and Victims, restitution should be arranged within thirty days since court decision is issued, or it can be extended to 14 days when arrangement cannot be fulfilled within thirty days, and the restitution can be paid in installments, as intended in Article 35 of Government Regulation. Each installment and payment delay must be reported by the victim, the victim's family, or another person/party assigned to LPSK and further passed to general prosecutors. The provision of Article 35 basically gives a chance that could trigger any uncertainty in the measure law enforcers have to take in case of absence of restitution payment to the victim with the amount agreed. Another inadequacy lies in the form of the sanction imposed on the offender due to discontinuance of installment.

When the offender refuses to give full payment of the restitution or stops paying the rest of the amount of restitutions as installments, seizure of assets may be involved to cover the unpaid restitution for the sake of the victim. This measure can refer to Executorial Beslag as governed in Civil Law.

3.2.2. The implication of Loophole and Inadequacy in the Government Regulation concerning Arrangement of Compensation, Restitution, and Aid for Witnesses and Victims

Legal loophole or inadequacy in the arrangement of restitution as mentioned above will lead to an issue the victim has to face to gain legal certainty. The victim in this case deserves legal certainty, as in line with Unicuique suum tribuere justice is present when particular rights are given to those deserving.

Failure to pay back the loss by paying restitution according to court decision may lead to further loss faced by the victims, and this failure may also lead further to the following legal consequences:

1) No justice is given to the victims

2) No merit the victims can gain

3) No legal certainty the victims could have to gain their rights to restitution.

${ }^{20}$ Lollar, C. (2014). What is Criminal Restitution. Iowa Law Review, 100, p. 7 
These three legal consequences are further elaborated in the following:

1. The consequence of failure to achieve justice

Certainly, the conflict between the legal loophole over the arrangement of restitution given in installments as in the government regulation as mentioned earlier and the values of justice will make victims suffer more. The connection between the concept constructed in the restitution and restorative justice highlights injustice due to the conflict. Thus, true justice represents what is mandated in restorative justice, where redress is paid to the victim and there should be good faith regarding the liability of the offender to help to recover the situation caused by the offense he/she commits. ${ }^{21}$

As a result, when the values growing from restorative justice fail to form, the main objective of restitution that is intended to redress the loss the victim suffers from is not achieved, and, thus, no justice is provided for the victim. Hans Kelsen, in "General Theory of Law and State", describes law is a social order which can determine "justice" if the law has a function to regulate social behaviors in the satisfaction way, then the society can feel happiness. 22 Thus, the law in practice must be able to regulate human behaviors in a satisfactory way, so through those conditions, it can make happiness towards society. The law that does not bring satisfaction to society will harm the values of happiness in people's lives.

Regarding the weaknesses of the Government Regulation concerning Compensation, Restitution, and Aid for Witnesses and Victims, it is clear that this regulation does not bring happiness to people's lives. The absence of a provision that addresses the solution when the offender does not intend to pay the restitution brings injustice to the victims. With regard to this, Jeremy Betham, notable for his utilitarian theory, sees the system of law and justice as an instrument to provide absolute happiness for the majority. In other words, the main objective of law and legislation is to give the greatest happiness to most people. ${ }^{23}$ This theory is mainly emphasized the greatest benefit for the majority. ${ }^{24}$

Contrary to this, the arrangement of restitution as governed in the mentioned Government Regulation fails to give benefits, especially to the victim of crime since it provides no solution when the offender does not intend to give restitution. There is no definitive mechanism to which the law enforcement officers may refer in dealing with the delay or refusal of the restitution payment. It is clear that happiness and utility as promoted in Jeremy Bentham's Utilitarian theory are compromised.

2. The consequence of failure to achieve legal certainty for the victim to gain his/her restitution

Legal certainty is legal protection against any arbitrariness. This guarantees a person to gain value as expected. ${ }^{25}$ Legal certainty should be assertively implemented in societies under any circumstances.

\footnotetext{
${ }^{21}$ Yulia, R. (2012). Keadilan Restoratif dan Korban Pelanggaran HAM (Sebuah Telaah Awal). Jurnal Hukum dan Peradilan, 1(3), p. 283

${ }^{22}$ Kelsen, H. (2011). General Theory of Law and State. Translate by Rasisul Muttaqien, Bandung: Nusa Media. p. 7

${ }^{23}$ Gunawan, T.J. op.cit., p. 32.

${ }^{24}$ Marlina \& Zuliah, A. op.cit., p. 35.

25 Margono. (2019) Asas Keadilan, Kemanfaatan dan Kepastian Hukum dalam Putusan Hakim. Jakarta: Sinar Grafika, p. 115.
} 
Legal certainty is guaranteed when the state is well supported by adequate facilities and effectiveness to run existing rules. On the other hand, this guarantee fails, and the effectiveness of enforcement is out of the question when there are legal loopholes and vagueness of or conflict between norms. Therefore, legal loophole hampering the process of restitution arrangement fails to provide legal certainty that should be enforced as a legal objective. As we know, the aim of law according to Gustav Radburch consists of 3 components, namely: justice, utilization and legal certainty in its implementation.

\section{Conclusion}

The legal loopholes of liability over delay or refusal of restitution payment have brought about some negative consequences for the victims. It has created legal uncertainty for victims in pursuing restitution and this has exposed them to injustice. In regard to this, the related legislation fails to promote happiness and therefore losses its utility for society, especially the victim of crime. It is clear that the ultimate values of law, namely justice, utility and certainty are compromised. In order to address this issue, a mechanism that ensures the payment of restitution is required. It is recommended that the mechanism should facilitate the seizure of the offender's asset which can be substituted with imprisonment in case the offender cannot afford the payment of restitution.

\section{References}

\section{Books}

Farhana. (2012). Aspek Hukum Perdagangan Orang di Indonesia. Jakarta: Sinar Grafika.

Gosita, A. (1987). Viktimologi dan KUHAP. Jakarta: Akademika Pressindo.

Gunadi, I. \& Efendi, J. (2014). Cepat \& Mudah Memahami Hukum Pidana. Jakarta: Kencana.

Gunawan, T.J. (2018). Konsep Pemidanaan Berbasis Nilai Kerugian Ekonomi. Jakarta: Kencana.

Harahap, Y. (2012). Pembahasan Permasalahan dan Penerapan KUHAP. Jakarta: Sinar Grafika.

Kelsen, H. (2011). General Theory of Law and State. terjemahan oleh Rasisul Muttaqien, Bandung: Nusa Media.

Margono. (2019). Asas Keadilan, Kemanfaatan dan Kepastian Hukum dalam Putusan Hakim. Jakarta: Sinar Grafika.

Marlina \& Zuliah, A. (2015). Hak Restitusi terhadap Korban Tindak Pidana Orang. Bandung: Refika Aditama.

Meliala, D. (2014). Hukum Perdata dalam Prospektif BW. Bandung: Nusa Aulia.

Salim HS. (2013). Pengantar Hukum Perdata Tertulis (BW), Jakarta: Sinar Garfika.

Sunarso, S. (2012). Viktimologi dalam Sistem Peradilan Pidana. Jakarta: Sinar Grafika.

United Nations Office on Drugs and Crime. (2006). Handbook on Restorative Justice Programmes. New York: United Nations Publication. 
Yulia, R. (2013). Viktimologi Perlindungan Hukum terhadap Korban Kejahatan. Yogyakarta: Graha Ilmu.

\section{Journals}

Al-Eifan, M. \& Alayash, M. (2014). Victim Restitution in the Kuwait Legal System: A Criminal or Civil Remedy? Comparative Analysis. International Review of Penal Law, 85, p. 701

Ali, M. \& Wiboro, A. (2018). Kompensasi dan Restitusi yang Berorientasi pada Korban Tindak Pidana. Yuridika, 33(2), p. 268

Flora, H. S. (2017). Pendekatan Restorative Justice dalam Penyelesaian Perkara Pidana dalam Sistem Peradilan Pidana di Indonesia, Law Pro Justitia, 2(2), p. 54.

Lollar, C. (2014). What is Criminal Restitution. Iowa Law Review, 100, p. 7

Marasabessy, F. (2015). Restitusi bagi Korban Tindak Pidana: Sebuah Tawaran Mekanisme Baru. Jurnal Hukum dan Pembangunan, 45(1), p. 55

Mareta, J. (2018). Penerapan Restorative Justice melalui Pemenuhan Restitusi pada Korban Tindak Pidana Anak. Jurnal Legislasi Indonesia, 15(4), p. 313

Ransun, A. R.V. (2012). Mekanisme Pemberian Kompensasi dan Restitusi bagi Korban Tindak Pidana, Jurnal Lex Crimen, 1.

Satria, H. (2018). Restorative Justice: Paradigma Baru Peradilan Pidana. Jurnal Media Hukum, 25(1), p. 117

Sosiawan, U.M. (2016). Prespektif Restorative Justice sebagai Wujud Perlindungan Anak yang Berhadapan dengan Hukum. Jurnal Penelitian Hukum De Jure, 16(4), 426.

Yulia, R. (2012). Keadilan Restoratif dan Korban Pelanggaran HAM (Sebuah Telaah Awal). Jurnal Hukum dan Peradilan, 1(3), p. 283

\section{Legislations}

Law No. 31 of 2014 concerning Amendment of Law No. 13 of 2006 concerning Protection of Witnesses and Victims

Government Regulation No. 7 of 2018 concerning Compensation, Restitution, and Aid for Witnesses and Victims 